\author{
Н.М. Сарбаева ${ }^{1}$, М.О. Омурбекова ${ }^{1}$, У.К. Жээнбаев ${ }^{1}$ \\ ${ }^{1}$ КГУСТА им. Н. Исанова, Бишкек, Кыргызская Республика
}

\author{
N.M. Sarbaeva ${ }^{1}$ ，M.O. Omurbekova ${ }^{1}$ ， U.K.Jeenbaev ${ }^{1}$ \\ ${ }^{1}$ KSUCTA n. a. N. Isanov, Bishkek, Kyrgyz Republic \\ nadir12sm@mail.ru
}

\title{
THE PROBLEMS OF INCREASING ENERGY EFFICIENCY IN RESIDENTIAL BUILDINGS
}

\section{ПРОБЛЕМЫ ПОВЫШЕНИЯ ЭНЕРГОЭФФЕКТИВНОСТИ ЖИЛЫХ ЗДАНИЙ}

Данная статья посвящена одной из важнейших проблем ХХІ века энергоэффективности и энергосбережению жильх зданий. Актуальность выбранной темь обусловлена тем, что энергосбережение и энергоэффективность зданий представляют собой важные сферы начиональной экономики. В работе рассмотрены основные проблемь повышения энергетической эффективности строящихся и существуюших жильх зданий республики. Представлены возможности по преодолению барьеров, направленные на совершенствование энергосберегающей деятельности при строительстве и эксплуатации жильх зданий. Отмечены основные пути организационного характера по повышению энергоэффективности жилых зданий за счет последовательного проведения энергообследований и реализачии эффективных энергосберегающих мероприятий. Сформулированы выводы по развитию комплексного и системного подхода мероприятий с целью усиления организаџионньх структур управления энергоэффективностью жильх зданий.

Ключевые слова: Энергоэффективное жилье, энергосбережение, тепловые потери, барьеры, энергетический аудит, законодательные акты.

This article is devoted to one of the most important problems of the XXI century - energy efficiency and energy saving of residential buildings. The relevance of the chosen topic is due to the fact that energy saving and energy efficiency of buildings are important areas of the national economy.

The paper considers the main problems of increasing the energy efficiency of construction and existing residential buildings in the republic.

Opportunities for overcoming barriers aimed at improving energy-saving activities in the construction and operation of residential buildings are covered. The main ways of an organizational nature to improve the energy efficiency of residential buildings through consistent energy studies and the implementation of effective energy saving measures are noted.

Conclusions are formulated for the development of an integrated and systematic approach of measures in order to strengthen the organizational structures of energy efficiency management in residential buildings. legislation.

Key words: Energy efficient housing, energy saving, heat losses, barriers, energy audit,

Purpose of the article: to present possible ways to reduce energy consumption to improve the energy efficiency of buildings.

Energy security problems are becoming more acute every year, relevant both throughout the world and in Kyrgyzstan. The level of energy intensity of the gross domestic product of the republic 
as a whole remains high. The main factors influencing this situation are the low level of modernization of the economy and uncontrollable demand for energy resources. Electricity consumption is increasing every year due to an increase in housing utility demand and population, which consumes $76.6 \%$ of all electricity supplied to the domestic market; industry - 19.1\%, agriculture $-2.5 \%$, transport $-0.4 \%[2]$.

The housing and utilities today is characterized by irrational consumption of thermal energy, the use of inefficient in terms of energy savings, development projects and building materials. Apartment devices for regulation of consumption and metering of consumption of heat energy, gas and water are installed in insufficient quantities. Heat losses of the housing stock are several times higher than in countries with a similar climate [1].

Modern construction in general is characterized by excessive consumption of building materials and energy resources, using ineffective building structures and materials and low quality of construction work. The number of energy efficient buildings under construction is not so large as to significantly affect the level of energy consumption of the entire construction complex.

This state of affairs is facilitated by the lack of an appropriate regulatory and legal framework, an information base, a market for energy-saving equipment and technologies, financial resources from potential manufacturers and consumers of products, and significant difficulties in obtaining loans for innovative developments [3]. Until now, the state has not provided budgetary support for the development and implementation of energy-saving technologies.

It is necessary to take measures to reduce energy consumption, conserve existing energy resources and create new ways to improve energy efficiency in the construction industry, which reduces operating, including utility costs, contributes to creating more comfort, a healthy and safe indoor environment.

Along with the increase in the thermal resistance of the building envelope, there are many other issues that hinder the work on energy saving. Currently, Kyrgyzstan is faced with the task of transitioning to innovative and energy efficient development.

Let us consider in more detail the possibilities for overcoming barriers:

1) Insufficient regulation.

Despite the introduction of regulatory documents concerning the implementation of energy saving measures, the problems of energy saving in Kyrgyzstan affect almost every sector of the economy[4]. What are these energy saving problems?

Due to the fact that the existing regulatory acts have an indirect rather than direct purpose, they do not have a significant impact on improving the energy conservation policy in the republic, that is, for their practical implementation, specific bylaws and instructions were not developed, and there was no clear division of responsibility for each job and incentives.

The energy saving fund proposed in accordance with the law turned out to be an inoperative financial instrument, since specific mechanisms of budget support were not worked out with the Ministry of Finance of the Kyrgyz Republic.

2) Weak use of alternative energy sources in construction.

Alternative energy is a promising area, gradually replacing the use of hydrocarbons. In connection with the aggravation of the problems of saving energy resources and protecting the environment, this issue has grown sharply.

The most popular alternative energy sources used in energy efficient homes are solar panels and collectors, wind farms and heat pumps. The climate of the republic can allow the use of natural heat due to sunlight, and mountains with increased availability of wind allow converting wind energy into mechanical or electrical energy, which can then be used in microclimate systems.

The total hydropower potential of Kyrgyzstan is about 142 billion $\mathrm{kWh}$, while the percentage of the development of the hydropower potential is only $10 \%$;

3) Lack of mandatory energy audit and assignment of an energy efficiency class to buildings under construction and existing ones. 
Building codes are a widely used energy efficiency tool in other countries and are often mandatory. Similar norms exist in Kyrgyzstan, but they are voluntary in nature, which may call into question the improvements achieved in recent years in energy efficiency in buildings. To prevent this, it is necessary to make the requirement of regulatory documents for the energy efficiency class of the building as the minimum permissible and mandatory for use.

In order to decide how to save and what effect can be obtained at the same time, it is necessary to determine how much energy actually enters the apartment building and how it is spent. For this, an energy audit is used, or a comprehensive study of the consumption of thermal and electrical energy in the house, identifying the possibility of optimizing its consumption. Only after determining the losses of all types of energy can plans of measures to reduce them be developed. Especially multi-storey buildings need to maintain an energy efficiency class. Of course, the higher the energy efficiency class, the lower the costs of residents for utilities.

4) The problem of using modern ventilation systems in construction and reconstructed buildings.

Most of the typical buildings in the cities of the republic have natural (or gravitational) ventilation, which is extremely ineffective and leads to significant heat loss. In the summer, such a system does not work at all, and in winter, constant ventilation is needed to get fresh air.

A modern ventilation system with heat recovery is proposed, which makes it possible to ensure a constant flow of fresh air into the apartments without having to open the windows. Installation of an air heat exchanger allows the use of already heated air for heating the incoming air and vice versa. Such a system is capable of providing 60 to $80 \%$ of the heat due to air heating. During the heating season, savings are more than $50 \%$ [5].

5) Lack of incentive programs to support manufacturers of energy-saving products.

The emerging situation in the field of energy conservation without active government intervention can largely further worsen the energy security of the country as a whole, as well as reduce the level of competitiveness of the economy. With the existing fuel and energy balance and the state of energy conservation, the growth of production volumes in the economy will necessitate an increase in the generation and supply of energy and fuel.

In the republic, very little is imported and produced using energy-saving equipment and materials, and advanced energy-saving technologies are poorly introduced.

6) Weak organizational measures to ensure energy saving measures.

"Energy saving measures - organizational, legal, technical, technological, economic and other measures implemented at the facility in order to reduce energy consumption and aimed at saving energy resources."

Recognizing the importance of energy as a resource that requires the same management as any other high-value resource and not as an enterprise overhead is a major first step towards improving energy efficiency and reducing energy costs. The stage of assessing the economic effect of introducing energy-saving measures and assessing their energy-saving potential becomes important.

7) Lack of highly qualified specialists in the field of energy saving.

Despite the presence of specialists in the field of energy and construction, today the staff in the profile of energy saving and energy efficiency does not meet the required level for various reasons. In educational institutions, there are practically no specialized narrow profiles in the direction of training energy efficient personnel.

8) Weak financial mechanisms.

The issue of financing is especially relevant. It is insufficient. An important role in the functioning of the financial mechanism for energy saving and energy efficiency is played by state regulation in this area, as well as stimulating the attraction of investments for the implementation of projects. In addition, if we consider the state impact in the field of energy conservation and energy efficiency, then it must be borne in mind that it is carried out not only in the sectoral context, but also from the standpoint of the country's environmental and environmental policy. 
At present, the experience of financing energy saving projects from banks is insufficient in the republic. If in other countries this sphere is actively developing and there are flexible financial schemes, in Kyrgyzstan there are no such perspectives yet;

9) Weak information support.

The energy efficiency management information system is an effective tool that allows you to build the processes of energy consumption accounting, planning, development and implementation of energy saving measures, generate reports, analyze data obtained at all stages of information collection and, on their basis, predict energy consumption [6].

Information support in the republic is also poorly developed. The peculiarity of the Kyrgyz mentality, "do it like everyone else", determines the lack of interest in the search for alternative energy saving solutions and their practical application.

It is necessary to create a state information system in the field of energy conservation and energy efficiency. Organizations as public authorities, local authorities should distribute information and educational programs on measures and methods of energy saving and energy efficiency increase, top success examples, including foreign ones, as well as other relevant information in this area.

\section{Conclusion.}

In view of the limitedness of exhaustible natural resources and the constant increase in their value, the reduction of energy costs, the development, design and construction of energy-efficient and energy-saving buildings and structures is an urgent problem.

The information presented proves that solving the problem of energy saving requires an integrated and systematic approach, in connection with which it is necessary to increase the level of coordination of actions in a number of areas:

- regulatory support,

- organization and management,

- scientific support,

- technical and technological measures,

- tariff regulation, production of energy-saving equipment

- economic incentives for energy conservation, training.

Solving the problem requires the use of organizational and financial mechanisms of interaction, coordination of efforts, concentration of resources of economic entities, taking into account the emerging unified energy efficiency management system in Kyrgyzstan.

A significant reduction in wasteful energy consumption in all fields of life cannot be ensured independently by the owners of facilities and structures. The task of radically increasing the level of energy efficiency can only be solved by program-targeted methods. Of course, all this will require colossal costs, but a building built in accordance with modern energy efficiency standards can save 40 to $70 \%$ of utility bills. A huge amount of energy and resources are saved. At the same time, the general indicators of temperature, favorable microclimate, air humidity turn out to be an order of magnitude higher than the generally accepted ones and are regulated by the owner of the room.

Therefore, we believe that these problems need to be addressed with a systematic approach through a combination of measures related to both the architecture and configuration of the building, planning solutions and thermal protection, as well as efficient heating and ventilation, as well as effective financing. That is, we need joint efforts of scientists, architects, designers, heat supply specialists, power engineers, managers of construction complexes and housing and utility services, developers, so that the problems that increase the energy efficiency of the construction complex are solved step by step.

These methods can significantly reduce heat consumption for heating and ventilation of buildings and structures during the cold season, increase their energy efficiency and reduce the use of energy resources. 


\section{Bibliography}

1. Matieva A.K. Features of the construction of a passive house. Materials Science. No. 1/2016 (12). S.58-63.

2. Kasymov T.M., Ismailov U.Z. Improving energy saving and energy efficiency of buildings and individual residential buildings in the Kyrgyz Republic №1 / 2018 (12) - 14 p.

3. Normative base of the Kyrgyz Republic in the sphere of energy saving [Electronic resource]. Access mode: http://energy.unison.kg/ru/content/normativnaya-baza. Portal for energy consumers (date of access 06.05.2019).

4. Matrosov Yu.A. Energy saving in buildings. The problem and ways to solve it. - M., NIISF, 2008. - 496 p.

5. Sarbaeva N.M. Some approaches to improving the energy efficiency of residential buildings. - B., Bulletin of KRSU, 2020. Volume 20. No. 8. - p. 26-30.

6. Shilkin N.V. Energy efficient houses in Denmark. /N.V. Shilkin, A.E. Nasonova// Buildings of high technologies. 2014. Summer. S.72-78. 